\title{
10. Of Time and the Textbooks
}

Is the latest textbook necessarily the most up-to-date? Twelve new (since mid-1956) textbooks on besic national government were found to contain little or no reference to two new developments of some import. The author concludes that the latest text provides instructors with no reliable substitute for individual initiative in keeping informed.

Social scientists generally use the latest textbooks. It is assumed that there is an advantage in a book of recent vintage--that the latest material is included in the latest book. This assumption seemed worth testing, albeit in an unscientific and comparatively unsystematic way.

Two items of information were selected as tests of the time lag inherent in the publishing process. Without thought of praise or blame it was assumed that some advantage would result from such an investigation of inclusion of material in recent textbooks. Two basic items of different levels of specificity were chosen as tests.

One item was a very specific, low-level datum. The Supreme Court of the United States has traditionally met on Saturday for a conference date. Beginning with the fall of 1955 the Court changed this practice and began to meet for its conference on Friday. This was announced on June 6,1955 . (See 349 U. S. 971 1955\%.) Since the Court had traditionally met on Saturday and had been doing so for a number of years, the item was well publicized in the newspapers and even in scholarly publications.

The second item was a more challenging and basic one. Robert Brown has now published two books in which he presents his interpretation of the colonial period. One of them, Middle-Class Democracy in Revolutionary Massachusetts, was a prize-winning book selected by the American Historical Association. The other is a direct challenge to Charles Beard and his economic interpretation of the
Constitution. Both works form a compact patterned whole and are part of Brown's fundamental reevaluation of colonial and revolutionary America. It is Brown's contention that, in fact, the colonial period saw no great extremes of wealth and poverty, but rather that it was a middle-class society in which most men owned property. In line with this and as essentially proving his thesis, Brown contends that the right to vote in the revolutionary period was much more widely distributed than has been usually assumed. The property requirements that are made so much of in most writings were, according to him, nominal and reasonable ones that could be met by most people in this middleclass society. Mr. Brown thus. challenges not only the Beard thesis, but also the works of A. M. Schlesinger, Sr., and F. J. Jameson, as well as the writings of A. E. McKinley. The crux of $\mathrm{Mr}$. Brown's argument hinges upon his contention that demographically only from nineteen to twenty per cent of the population were adult males. Thus the estimates that $12-18 \%$ of the population could vote meant that up to $90 \%$ of the adult white males were franchised.

Although Brown is an historian, his works were fairly widely reviewed and evaluated. He received a rather unusual compliment, for example, in having his two books reviewed back-to-back in The American Political Science Review in December of 1956 . Certainly an argument that from eighty to ninety per cent of the adult white males could vote in the postRevolutionary period is a challenging one and one that compels at- 
tention by the political scientist.

Twelve textbooks on basic national government were selected as the sample for this study. They included the most recent version of the texts by the following: Bailey and Associates; Binkley and Moos; Bruce; Burns and Peltason; Carr and Associates; DeGrazia; Ewing; Ferguson and MiHenry; Gosnell and Associates; Maxey and Fluno; McCamy; and Young's Ogg and Ray. These included all basic textbooks available at the time of the inquiry and all but one of those currently advertised in The American Political Science Review. All books chosen had a copyright date of 1956 or beyond, and others indicating that they had been written in the early part of 1956 were not considered.

Of the even dozen textbooks, nine still discussed Saturday as the conference date for the Supreme Court, two had no mention of the time of conference, and only one had correctly stated the date as Friday. The text that included the Friday date was not the latest book in time.

\section{A further issue developing out} of the study of the conference was the indication that, in book after book, the discussion of the Supreme Court's conference was a rather close paraphrase of an article by Arthur Schlesinger, Jr., which had appeared in Fortune magazine some time ago. Since Schlesinger's article was highly interpretative, the point of view expressed by him also tended to be reflected in these treatments. Fully half of the textbooks thus had been treating the Court in the terms set by Schlesinger's article.

More interesting is the failure of any textbook to wholly absorb the material in Brown's two books. Only one textbook of our twelve mentions Brown at all, and this only as a direct confrontation by Brown of the Beard thesis. No book includes Brown's data on voting behavior. To be sure, of the twelve textbooks only six deal directly with history and historical statements on voting. A number of others do have generalized statements (mostly on the order of quotations from people of the time rather than statistics on voting), and thus they might find the Brown material not directly relevant to their own treatment. On the other hand, half of the books do have statements with regard to the extent of voting and thus presumably should have found the material appropos.

In one instance an author did present the new information with regard to voting behavior in the teaching manual that was later prepared to accompany the textbook. However, since in the manual he gave no indication of the source of his correction, the statement could not serve as a stimulus to either teacher or student to further understand the implications of this new argument.

A check of four textbooks in American political parties published since 1956 also shows no inclusion of the Brown material, although three of the books had the results of previous research on this question.

Those works that included data on voting were scrupulously fair and, on the whole, extremely accurate in presenting the figures and in drawing no further conclusions from them than were justified by the facts as stated. In general they showed a very high level of scholarship in dealing with already established facts and interpretations. The inclusion of newer material apparently presented a more difficult problem, however.

Even where the author was a specialist in the sub-section of political science in which the item was relevant this proved no advantage in its inclusion in the textbook. This proved to be the case in both instances in our inquiry.

In sum, it would appear that the exigencies of book publishing and the flow of events is such that 
no textbook can be assumed to incorporate even all of the leading changes of recent vintage in the field. In the end, the teacher must rely upon his information and knowledge to supplement the textbook. The time lag between manuscript and book, the time lag between event and incorporation is such that there is inevitable delay in bringing in new material. The task of covering an entire field of learning is such that it is difficult to spot immediately those new items that bear upon the totality of the text as it exists and incorporate the material. In the end, the teacher must, through his own creative efforts, bear the responsibility of bringing to his students the newest and the best in modern research.

- -Sam Krislov University of Oklahoma

\section{Annotated BIBLIOGRAPHY on Political Research}

(Selection based upon a search of 132 journals, lists of government documents, and Publisher's Weekly, published or received in this country since the preceding issue of PROD.)

Agger, R. E., \& D. Goldrich, "Community Power Structures and Partisanship." Amer. Soc. R., XXIII (Aug. '58), 383-92, Comparative study of local politics in two Far Western communities, 1953-54. Takes into account loyalties, natural organization, local power, economic, and social structure.

Allen, F. R., "Civil Defense and Regions: An Exploratory Study. "Social . Forces, XXXVI (Mar. '58), 239-46. How adequately CD regions are manned, with suggestions for much more research on comparative needs of the regions for defense.

Angell, R. C. Free Society and Moral Crisis. Ann Arbor: U. of Mich., . 1958. Investigates the moral problems and problems of social integration peculiar to our technical society with its pluralistic value systems.

Arambourou, R., "Cadastre et Sociologie Electorale." Revue Francaise de Sci. Pol., VIII (June '58), 368-83. Uses the register of lands as a source of data for a new approach to the sociology of the French electorate, in a region of the Gironde.

Atkinson, J. W., ed. Motives in Fantasy, Action, and Society. Princeton: Van Nostrand, 1958. Psychological studies of three social motives of achievement, affiliation, and power.

Augustine, T., "The Negroes' Progress Toward Employment Equality." Personnel and Guidance J., XXXVI (May 158), 632-34. Negro employment in various job categories is computed for 1940 and 1950 , and projected into the future; employment equality is being approached more quickly by Negro women than by Negro men.

Bauer, R. A., "Brainwashing: Psychology or Demonology?" J. of Social Issues, XIII (\#3), 41-47. The key to political loyalty in the Soviet system is the control of the State over the entire life situation of the individual; "brainwashing" is a special application of this principle.

Beloff, M. The Tasks of Government. N. Y.: Oxford, 1958 . (Paper.) Inaugural lecture, University of Oxford, February 20, 1958.

Black, D. The Theory of Committees and Elections. N. Y.: Cambridge U. Press, 1958. Logic of committee decisions and of elections; history of mathematical theory of committees and elections (incl. PR).

Blair, L., "The Civil Servant--A Status Relationship?" Modern Iaw R., XXI (May 158), 265-76. Argues that the crown-civil servant relationship is as truly one of legal status as is that of the armed forces, and not exclusively contractual. 
Blondel, J., "The Conservative Association and the Labour Party in Reading." Pol. Studies, VI (June '58), 101-19. Close analysis of party structures concludes that both parties are becoming more alike in that they are both becoming more organized; both parties have had a new distribution of power caused by new sources of incoms.

Blyth, W. A. L., "Sociometry, Prefects and Peaceful Coexistence in a Junior High School. "Soc. R., VI (July '58), 5-24. Describes the exposure through sociometric techniques of an unsuspected class cleavage among pupils in an English junior school, demonstrating the effectiveness of this instrument.

Bonnor, J., "The Four Labour Cabinets." Soc. R., VI (July '58), 37-48. Analysis of social origins of cabinet ministers through the 4 labour cabinets in England since 1924, showing an increase in ministers from the middle classes and a decrease in those from the highest and lowest classes, hence that Labour Cabinets have increasingly resembled cabinets formed by other parties with respect to class structure.

Bourricaud, F., "Science politique et Sociologie. " Revue Francaise de Sci. Pol., VIII (June '58) 249-76. A sociologist's evaluation of the possibilities for rapport between political science and sociology, with a critique of the comparative method.

Brown, J. C., "Local Party Efficiency as a Factor in the Outcome of British Elections." Pol. Studies, VI (June (58), 174-78. Using D. Butler's study of 155 general election as point of departure, computations and analysis indicate that influence of local party machine seems likely to vary directly with its organizational efficiency and inversely to the safety of the seat and the intensity of voters' interests in the issues of the election.

Buckley, W., "Social Stratification and the Functional Theory of Social Differentiation." Amer. Soc. R., XXIII (Aug. '58), 369-75. A criticism of the functionalist definition of social stratification, which "jettisons much of the previous work" and promotes "discontinuity in sociological research."

Carlson, L. Geography and World Politics. Englewood Clifis, N. J.: Prentice-Hall, 1958 .

Carlsson, G., "The Role of Hypotheses in Sociological Research. "Acta Sociologica, III (\#1), 8-18. Pro and con discussion of use of advance hypotheses in research planning, concluding that it has some important limitations and should not be considered normative.

Clark, S. D., "The Support of Social Sciences Research in Canada. " Canad. J. of Econ. \& Pol. Sci., XXIV (May '58), 141-51. On problems confronting Canadian researchers.

Coehlo, G. V. Changing Images of America. Glencoe, Ill.: Free Press, 1958. Sociological study of changing attitudes of several Indian exchange students toward America during their stay.

Dahl, R. A., "A Critique of the Ruling Elite Model." Amer. Pol. Sci. R., LII (June '58), 463-69. Suggests a test for any hypothesis that asserts a particular political system is ruled by a definable elite.

Deutsch, K. W., "The Place of Behavioral Sciences in Graduate Training in International Relations." Behavioral Sci., III (July '58), 278-84. The student of int'l relations should now be not only a gentleman and scholar, but also a scientist.

Dodd, S. C., "Ten Semantic Tangles and the Threat of War. "Journalism Q., XXX́V (Spring '58), 170-76. Analysis of semantic confusions in terms of failure to specify the traditional "who, when, etc.", or failure to tell which case, degree, class or level.

Durkheim, E. Professional Ethics and Civic Morals. Glencoe, Ill. : Free Press, 1958. Lectures on professional ethics, civic morals and the relation of these to the State, the individual, democracy, and property.

Edelman, M., "Causes of Fluctuations in Popular Support for the Italian Communist Party Since 1946." J. of Pol, XX (Aug. '58), 535-52. 
For a decade the Italian Communist Party has drawn its supporters from those who feel overwhelmingly threatened by economic or political situations. Statistics indicate Italian communism is an increasingly rural phenomenon.

Eitington, J. E., "Liberal Learning for Enlightened Leadership. " Personnel Admin. ' XXI (July-Aug. '58), 8-19. Review of some recent efforts by enterprise to increase "human and conceptual" skills in administrators through liberal arts workshops, courses, institutes.

"Employment of Social Investigation Reports in Criminal and Juvenile Proceedings." Columbia Law R. , LVIII (May '58), 702-27. Discussion of presentence reports by probation officers.

Eulau, H., "H. D. Lasswell's Developmental Analysis." Western Pol. Q., XI (June '58), 229-42. Collection of Iasswell's references on developmental analysis, with critique; author holds Lasswell does not carry developmental analysis to its "logical conclusion."

Fisher, F. M., "The Mathematical Analysis of Supreme Court Decisions: The Use and Abuse of Quantitative Methods. "Amer. Pol. Sci. R., LII (June '58), 321-38. Exploration with statement of author's concept of limitations of mathematical interpretations.

Forrester, J. W. , "Industrial Dynamics: A Major Breakthrough for Decision Makers." Harvard Business R., XXXVI (July-Aug. '58), 37-66. Stimulating description of new projective and prognostic theories and graphics used in analyzing industrial processes. (Perhaps adaptable to administrative and political cpinion analysis.)

Friberg, L. , E. Jonsson \& L. Strandberg, "Studies of 'Interviewer Effect' on a Medicohygienic Interviewer Survey. "Acta Sociologica, II (\#1), 1-7. Comparison of replies obtained in a survey indicated "interviewer effect" in half of the questions investigated--enough to invalidate findings by the survey method, if precautions in planning are not taken:

Glantz, O., "Class Consciousness and Political Solidarity." Amer. Soc. R., XXIII (Aug. '58), 375-83. "Class" is objective, not subjective. A Philadelphia study indicates that class consciousness leads to classrelated motives for political behavior.

Grainger, G. W., "Oligarchy in the British Communist Party. " Brit. J. of Soc, IX (June '58), 143-58. Analysis of moans by which British C.P. ensures that effective power is held by narrow group at top of party hierarchy.

Hauser, P. M. , ed. Population and World Politics. Glencoe, Ill . : Free Press, 1958. Papers on world population and resources, levels of living, economic development, population policy and politics.

Hornik, M. P. , "Had Hitler Jewish Blood?" Contemp. B, \#1111 (July '58), 28-31. Analysis of Hitler's behaviors in light of the theory that he believed himself of Jewish extraction. Off-beat, interesting.

Janowitz, M., "Social Stratification and Mobility in West Germany. "Amer. $\mathrm{J}$. of Soc', IXIV (July '58), 6-24. Data underline continuity of present West German social structure with that of prewar period but also record extensive upward and downward mobility of individual Germans.

Kort, F., "Reply to Fisher's 'Mathematical Analysis of Supreme Court Decisions'." Amer. Pol. Sci. R., LII (June '58), 339-48. More mathematical analysis needed in "unsettled" legal areas (e.g., domain of "fair trial" rule); argues that quantitative analysis makes a contribution if it can reveal pattern of consistency which cannot be detected by conventional qualitative evaluation.

Laponce, J. A., "Mendès-France and the Radical Party. "Western Pol. Q., XI (June '58), 340-56. Good study of party and legislative leadership.

Latham, E., ed. The Philosophy and Policy of Woodrow Wilson. Chicago: U. of Chicago Press, 1958. Essays by Link, Young, Dimock, etc., on leadership and policies of Wilson. Edited for APSA.

Leiserson, A. Parties and Politics. N. Y.: Knopf, 1958. "Institutional and behavioral approach." 
Leontief, W., "The State of Economic Science." $\underline{\mathrm{R}}$. of Econ. \& Stat, XL (May '58), 103-06. A critical review article of T. C. Koopman's Three Essays on the State of Economic Science (McGraw-Hill, '57). Book and review are basically concerned with separation of theorists from fact-finders in economic science.

Lifton, R. J., "Thought Reform of Chinese Intellectuals: A Psychiatric Evaluation." J. of Social Issues, XIII (\#3), 5-20. Excellent discussion of Chinese Communist political psychology as it impinges on the intellectual, in the context of Chinese culture. Based on extensive interviews of refugees.

Lindblom, C. E., "Policy Analysis." Amer. Econ, R., XLVIII (June '58), 298-312. An attempt to formalize a method of public policy analysis whose outstanding characteristic is "a close intertwining of the search for values and the search for facts."

London, I. D., \& N P. Poltoratzky, "The Problem of Contemporary Analysis in History and Psychology. "Behavioral Sci., III (July '58), 269-77. Concludes that classical nontransactional and nonsituational conception of objectivity must be re-evaluated.

Lord, E., "The Impact of Education on Non-Scientific Beliefs in Ethiopia." J. of Social Psych., XLVII (2nd half), 339-53. Study of effectiveness of Western educational methods and knowledge indicates that in a majority of cases older beliefs and superstitions have not been supplanted, even among teachers.

Macrae, D. G., "Politics: Necessary and Contingent." Pol. Q., XXIX (Apr.-June '58), 124-32. Remarks, some most eloquent, on how much of the political world is response to 2 attitudes, one that sees the world as necessary (coherent, significant, inevitable pattern) and the other as contingent (arbitrary, incoherent, and meaningless).

Macridis, R. C., ed. Foreign Policy in World Politics. Englewood Cliffs, N. J.: Prentice-Hall, 1958. Compares similarities and differences of contemporary foreign policy of a number of political systems.

Madden, C. H., "Some Temporal Aspects of the Growth of Cities in the United Statés. "Econ. Devel. \& Cultural Change, VI (Jan. '58), 143-69. An intensive study, based on a decade of census data, of the growth rates of American cities, and the influencing factors. A general tendency in cities over 100,000 is a decline in percentage rates of growth.

Marcus, J. T. French Socialism in the Crisis Years, 1933-36. N. Y.: Praeger, 1958. Analyzes structural contradi ctions in French socialism which produced splinter groups working at cross purposes.

Matossian, M. ", "Ideologies of Delayed Industrialization: Some Tensions and Ambiguities." Econ. Devel. \& Cultural Change, VI (Apr. ' 58), 217-28. Typical discussion of the role of the "assaulted" intellectual in industrially backward countries: he faces ideological conflict in borrowing from the West, as opposed to his own heritage.

McDougal, M. S. \& L. Lipson, "Perspectives for a Law of Outer Space." Amer, J. of Int']. Law, LII (July '58), 407-31. Legal speculation is approaching escape velocity, but is strongly marked by its earthly origins.

McKean, R. N. Efficiency in Government Through Systems Analysis. N. Y.: Wiley, 1958. Study directed at improvement of analysis in government and extension of its uses.

Milburn, J. F., "The Fabian Society and the British Labour Party." Western Pól. Q., XI (June '58), 319-39. Discussion of post-1920 period, with emphasis on Society rather than individual Fabians. Society's indirect influence assessed as "significant."

Miles, R. E., Jr., "The Orientation of Presidential Appointees: A Continuing Challenge." Pub. Admin. R. XVIII (Spring '58), 106-12. Shortcomings of presently conceived program include insufficient contact between new officials and the literature, academic centers, and "wise old birds" of pub. admin. \& Poli. Sci. Solutions suggested. 
Monsaroff, B. Economics, Science, and Productions. N.Y.: Vantage, 1958. Science as a politico-economic factor in foreign trade, business cycles, capital, labor, etc.

Morgenthau, H. J. Dilemmas of Politics. Chicago: U. of Chicago Press, 1958. Description of how modern political science is dealing with dilemma of disengagement from traditional dogma and application of ideas fitting the political experience of our age.

Mueller, G. O. W., "On Common Law Mens Rea." Minnesota Law R., XLII (May '58)', 1043-1104. Investigation into common law basis of mens rea, touched off by Lambert $v$. California, concluding that mens rea and intent are commonly and mistakenly confounded, and that statutes attempting to abolish a universal mens rea requirement are unconstitutional.

Natanson, M., "A Study in Philosophy and the Social Sciences. "Social Research, XXXV (Summer '58), 158-72. View of inadequacies in naturalistic interpretation of social sciences presented in historical framework. Author holds that inadequacies can be overcome by a phenomenological approach.

Newman, J. W. " "Working with Behavioral Scientists." Harvard Business R. 'XXXVI' (July-Aug. '58), 67-74. Resumé of conflicts in the research and consulting relation. "The very reasons why the behavioral sciences are important are also reasons why their use is opposed."

Noble, D. W. The Paradox of Progressive Thought. Minneapolis: U. of Minn. Press, 1958. Impact of post-W.W.I progressivism on climate of opinion in economics, political science, and sociology.

Nove, A., "The Politics of Economic Rationality." Social Research, XXV (Summer '58), 127-44. Observations on possible political implications of problems of economic rationality in Soviet Union.

Oppenheim, F. E., "An Analysis of Political Control: Actual and Potential." J. of Pol., XX (Aug. '58), 515-34. For the purpose of constructing empirical theories about political behavior, the author prefers to interpret "control" as "having control" rather than "exercising control."

Padover, S. K., "The World of the Founding Fathers." Social Research, XXV (Summer 158), 191-214. Culture and outlook of founding fathers caused their conviction that it was possible for people to govern themselves without abuse or injustice.

Passmore, J., "History and Sociology." Australian J. of Pol \& Hist, III (May '58), 218-28. History, as the mother discipline of many social sciences, can be and has been influenced in many ways by sociology.

Patai, R., ed. Current Jewish Social Research. N. Y.: Herzl Foundation, 1958. (Paper.)

Pepinsky, P. N., J. K. Hemphill \& R. N. Shevitz, "Attempts to Lead, Group Productivity, and Morale Under Conditions of Acceptance and Rejection." J. of Abnormal and Social Psych., LVII (July '58), 47-54. Leadership was evaluated under conditions of acceptance and rejection in four-man groups; to understand group behavior, the treatment of the leader by others must be taken into account, as well as his treatment of others.

Pitchell, R. J., "The Influence of Professional Campaign Management Firms in Partisan Elections in California." Western Pol. Q. , XI (June '58), 278-300. Professional publicity men have added efficient contact with voting population to Calif. electoral campaigns; have not overshadowed candidates' personalities.

Pye, L. W. "The Non-Western Political Process." J. of Pol., XX (Aug. '58), 468-86. Examination of ways in which particular non-Western countries differ from generalized models.

Redding, J. Inside the Democratic Party. Indianapolis: Bobbs-Merrill, 1958. 1948 campaign especially. 
Redlich, F., "Business Leadership: Diverse Origins and Variant Forms." Econ. Devel. \& Cultural Change, VI (Apr. '58), 177-90. The historical development of business leadership in various countries is described: many developmental patterns are apparent, some but not all of which may be encouraged in now underdeveloped countries.

Richard-Molard, J., "Collectivites et Collectivismes en Afrique Noire." L'Afrique et L'Asie, \#43 (1958), 3-15. A general structural discussion of race, language, and cultural areas in "black Africa," written in 1950 .

Riker, W. $\dot{H} .$, "The Paradox of Voting and Congressional Rules for Voting on Amendments." Amer. Pol. Sci. R., LII (June '58), 349-66. Suggests new rule; discusses shortcomings presently prevailing.

Roucek, J.S., "The Development of Political Geography and Geopolitics in the United States. "Australian J. of Pol. \& Hist., III (May '58), 204-17. Development and present standing of these two disciplines in the U.S.. emphasizing the Mackinder thesis.

Rywkin, M. S., "Education for Communist Leadership. "Current Hist., XXXV (July' '58), 35-39. "The efficiency of Soviet political education and its impact on the mass of Soviet citizens, and especially on the members of the Communist elite, is disproportionately weak in relation to effort, time and money expended."

Sayre, W. S., "Premises of Public Administration: Past and Emerging." Pub. Admin. R., XVIII (Spring '58), 102-05. From codification of premises, concepts, and data for the new public administration (1926-27); through assault on politics-administration dichotomy, claims to science and to universal principles of administration, "sociological" studies of bureaucracy (through W.W.II); to new consensus of public administration doctrine as culture-bound, public administration as one of major political processes, organization theory as problem in political strategy.

Scammon, R. M., ed. America Votes, Vol. II. N. Y.: Macmillan, 1958. New material on voting for Senator and on voting statistics of 55 and 157 primary elections.

Schur, E. M., "Scientific Method and the Criminal Trial Decision. "Social Research, XXV (Summer '58), 173-90. Obstacles to application of scientific method in determining guilt or innocence.

Schwartz, H., "The Renaissance of Soviet Statistics." R. of Econ. \& Stat., XL (May' 58 ), 122-26. Since 1956 statistics on Soviet economy prepared in the USSR have been detailed, comprehensive, and extremely useful.

Seeman, M., "The Intellectual and the Language of Minorities. "Amer. J. of Soc, LXIV (July '58), 25-35. Interviews of social scientists and humanists indicated many minority-like responses, concerning their identities as intellectuals.

Semmel, B., "Karl Pearson: Socialist and Darwinist." Brit. J. of Soc., IX (June' '58), 111-25. The origins and evolution of Pearson's early $20 t h$ century doctrines, which culminated in racism.

Senders, V. L. Measurement and Statistics. N.Y.: Oxford, 1958. Text emphasizing behavioral science applications of statistics.

Shaw, P., "Neue Form internationaler Demokratie." Aussenpolitik, IX (June '58), 351-57.

Smythe, H. H. "The Problem of National Leadership in Nigeria. " Social Research, XXV (Summer '58), 215-27. Examination of present political leadership in Nigeria; concludes that a "great man" could wield unifying power but that the chances of emergence of such a man are few

Spencer, R. F., "Cultural Process and Intellectual Current: Durkheim and Ataturk." Amer. Anthro., LX (Aug. '58), 640-57. The role of Mehmed Ziya Gbkalp as intellectual mentor to Kemal Atattrk's western ization and cultural unification of Turkey; influence of Durkheim's social theories on Ziya; example of correlation between social system and intellectual movement. 
Stark, W., "The Psychology of Social Messianism." Social Research, XXV (Summer '58), 145-57. Bentham, Thompson, Spencer, Comte, all suffered destruction of their mental frameworks from irresolvable conflict between intellect and soul.

Stokes, D. E., A. Campbell, W. E. Miller, "Components of Electoral Decision." Amer. Pol. Sci. R., LII (June '58), 367-87. Measures political attitudes (both individual and mass) and relates them to voting choices.

Strotz, R. H., "How Income Ought to be Distributed: A Paradox in Distributive Ethics." J. of Pol. Econ., LXVI (June '58), 189-205. A set of postulates is presented in formal notation--and stated informally-and from them a "fairly precise theorem about how income ought to be distributed" is derived. The postulates are claimed to have a "strong ethical appeal."

Stryker, P., "On the Meaning of Executive Qualities. "Fortune, LVII (June '58), 116-19. First of a series of articles in this field. A review of efforts to construct unambiguous yardsticks for measuring executive ability.

"What Makes an 'Emotionally Stable' Executive?" Fortune, LVII (July '58), 116-17. Discusses emotional stability under the aspects of self-control, frustration-tolerence, maturity, insight into self; points out semantic problems along the way. 2nd of series.

Talmon, J. L., "Social Prophetism in 19th-Century France. " Commentary, XXVI (Aug. '58), 158-72. Development of Saint-Simonist socialism, and the roles played in it by Jewish intellectuals.

Wallace, J. G., "The Tiv System of Election." J. of African Admin., X (Apr . '58), 63-70. The Tiv system is based on the principles of equality and patriarchy, but the latter in particular is degenerating under the impact of political modernization in Nigeria.

Wang, Y. C., "The Intelligentsia in Changing China." Foreign Affairs, XXXVI (Apr. '58), 315-29.

Weinberg, S. K. Culture and Personality: A Study of Four Approaches. Washington, D. C.: Public Affairs Press, 1958. (Paper.)

Westley, B. H., "Journalism Research and Scientific Method: I. " Journalism Q., XXXV (Spring '58), 161-69. An excellent survey of some of the methodology (or "strategy") of behavioral science especially as it compares with historiography. Good reading for students.

Willmott, P.. "Kinship and Social Legislation." Brit. J. Of Soc., IX (June ' 58 ), 126-42. In Britain, although the family is not the isolated and rootless unit it is commonly thought to be, official recognition of kinship liability has shrunk, while official recognition of kinship dependency has slightly expanded. There is no consistent legal position.

Yates, W. R., "Power, Principle, and the Doctrine of the 'Mouvement Républicain Populaire'." Amer. Pol. Sci. R., LII (June '58), 419-36. During first three years of movement's existence, Popular Republicans were driven by 2 incompatible aims: desire to spread ideals of Christian Democracy and desire for immediate electoral success.

Zaidi, S. M., \& M. Ahmed, "National Stereotypes of University Students in East Pakistan." J. of Social Psych., XLVII (2nd half), 387-95. Stereotypes of nine nationalities were obtained singly and in comparison; Americans were greatly favored over British and Russians. This is explained in historical terms.

Zander, A., "Group Membership and Individual Security. " Human Relations, XI (\#2), 99-110. An essay on the properties of groups which have consequences for the happiness and security of members--feelings of hostility, attraction, self-respect.

3oehm, G. A. W., "The New Mathematics." Fortune, LVII (June '58), 141-45. "The New Uses of the Abstract, "Fortune, LVII (July '58), 124-27. Part I: Recent pure mathematics, incl. aesthetics, utility, physical reality. Part II: Applied, incl. probability theory, game theory, competition, distribution of profits, computers, education. 